444

\title{
垂直底部面をもつ二次元鈍頭物体の流動抵抗に 及ぼすブロッケージ比の影響*
}

\author{
加 藤 征 三**, 社河内 敏 彦** \\ 隅山典 彦***，藤 本哲夫****
}

\section{The Blockage Effects of a Two-Dimensional Bluff-Based Body on Its Aerodynamic Drag Characteristic}

\author{
Seizo KATO, Toshihiko SHAKOUCHI, \\ Norihiko SUMIYAMA, and Tetsuo FUJIMOTO
}

\begin{abstract}
Measurements are performed on aerodynamic drag coefficients, $C_{D}$, of a two-dimensional bluffbased body over the range of blockage ratios of the body breadth to the wind tunnel width, $d / W=$ $0.1 \sim 0.4, C_{D}$ increases with an increase of $d / W$, exponentially at $d / W>3.5$, being subject to the blockage constraint. A modified drag coefficient $C_{D}^{\prime}$ introduced by the clearance freestream velocity between the body and the tunnel side wall, $U_{\infty}^{\prime}$, remains a constant value, independently of blockage ratios of $d / W<3.5$. $C_{D}^{\prime}$ implys the base drag coefficient without the blockage effects, $C_{D 0}$, and the latter may be predicted by an empirical formula $C_{D 0}=K^{2} \cdot C_{D}$ and $K=U_{\infty} / U_{\infty}^{\prime}=1-d / W-2\left(\delta_{b}^{*}+\delta_{w}^{*}\right) /$ $W$, where $\delta_{b}^{*}$ and $\delta_{w}^{*}$ are the boundary layer displacement thicknesses produced on the body and the tunnel wall. The drag characteristic is also discussed with the results of the pressure and velocity distributions around the body and the wake, the prevailing frequency of shed vortices, and the flow visualization.
\end{abstract}

Key Words: External Flow, Drag Coefficient, Bluff-Based Body, Blockage Effect, Wake

\section{1. 緒霄}

バスやトレーラトラックなどにみられる後端部に側 端面と直角の角をもつような鈍頭物体（Bluff-Based Body）まわりの流動特性を明らかにすることは，その 圧力抵抗を低減させる方法を確立することなどに関連 し重要である。

著者の一人は，先に上記鈍頭物体の圧力抵抗を隇少 させる方法の一つとして, 後端角部近傍に円弧状の力 イドベーンを設置し，主流の连動エネルギーを後流内 へ䅡極的に埒入することを試み，それによる後流制御 と压力抵抗との関係を実験的に明らかにした 際, 流体力測定は風洞の測定部壁面の影䡴が生じない よう供試物体の流れ方向と垂值な投影面䅡を風洞測定 部の断面䅡の $10 \%$ 以下にするとともに物体と風洞壁 面との距離を微調整して, 壁面に占ける圧力こう配が ない条件下で行った。すなわち，一様流中の物体の抵 抗を扱ったものである。

物体の流力特性を実験的に調べる場合，通常風洞ま

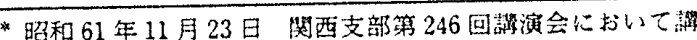
演，原筮受付 昭和61年5月 26 日.

**正員, 三望大学工学部（海514 律市上浜町 1515）。

****学织, 三诉大学大学院。

****正只, 名古屋大学工学部 (464 名古屋书千種区不老町).
た注水槽が用いられるが，この場合物体は有限の大き さをもつ流路中に設置される結果, 流路側壁の影嚮, すなわちブロッケージ比（流路の物体に対する閉そく 率)の影䅧を受ける。このことは，乗用車，バス，トラ ックなどの鈍頭物体の抵抗係数の測定において, 奏測 值のばらつきの主因子となりうるという問題点が指摘 されて抢り ${ }^{(2)}$ このブロッケージ比の影㵷を修正する 一般的整理法が望まれている。従来，物体の流力特性 に対するブロッケージ比の影響については，特に最も 基本的な形状である円柱については, Rosenhead

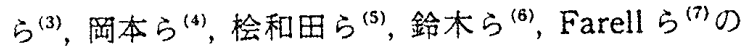
研究が，また垂直平板については平野ら ${ }^{(8)}$ の研究がみ られ，かなりのことが明らかにされてきている。しか し，工業上，より重要な上記鈍顗物体の流力特性に対 するブロッケージ比の影響についての解明はまだ十分 行われていない。

本研究は，供試物体として，前緣が半円形状を，後 端部が側端面と直角の底部面を有する二次元鈍頭物体 （以後，物体とよぶ）を用い，流力特性に及涩すプロッ ケージ比の影響を明らかにしたものである。本実験で は,プロッケージ比 $d / W$ を 0.1 0.4（d：物体の幅， $W:$ 流路幅)，レイノルズ数 $R_{e}=U_{\infty} d / \nu$ を $(1.5 \sim 9.0) \times 10^{4}\left(U_{\infty}\right.$ : 主流速度， $\nu$ ：動粘度)に変化さ 
せ抵抗力を測定するとともに,プロッケージ比の影響 を流動特性からも詳紐に検討するため，物体まわりお よび物体の後流の速度と王力分布，物体後端角部から 放出される洞の卓越周波数の湘定, 流れの可視化実験 などを行った。また，本物体の抵抗係数のプロッケー ジ比の影響を修正する一整理法も检討した。

\section{2. 実験装と方法}

図1に供試物体の形状・諸元を示す。物体は流入す る流れがはく離しにくい半円形(1)の前縁形状を，後端 部に側端面と直角の角をもつ底部（base）面をそれぞ れ有する二次元の鈍頭物体で，本体 A，およびそれと 同一断面形状を有する $\mathrm{B}, \mathrm{C}$ 部からなる。物体(幅 $d=$ $46 \mathrm{~mm}$ ) は, 風洞測定部（長さ $L: 3100 \mathrm{~mm}$, 高さ $H: 465 \mathrm{~mm}$, 幅 $W: 115 \sim 460 \mathrm{~mm}$ の範国で可変, こ れによってプロッケージ比を調整)の入口端から 1300 $\mathrm{mm}$ 後方の中央部に垂直に設置される.その際，B，C 部はそれぞれ測定部の上，下板に，A 部は 3 本のりん 青銅のはり（厚さ: $1.0 \mathrm{~mm}$, 幅 : $15 \mathrm{~mm}$, 長さ : 200 $\mathrm{mm})$ を用いて測定部とは独立して設けた枠組に固定 されている， B，C部は測定部上，下板上に生じる境界 層の影緇を除去し物体本体まわりの流れの二次元性を 確保するために設けたものて，各部はそれそれれ 0.8 $\mathrm{mm}$ の間げきを保って設置されている。

前記りん青鉰のはりの1本（中央のそれ）にはひず みゲージ(4ゲージ法)がて付されておりこれによ り物体本体が受ける流体力 Dの測定を行った。ひずみ ゲージの出力と流体力は，本実験筑四内では良い直線 関係を示した。測定される流体力は，王力抵抗と摩擦 抵抗の和であるが，そのほとんどは圧力抵抗であると

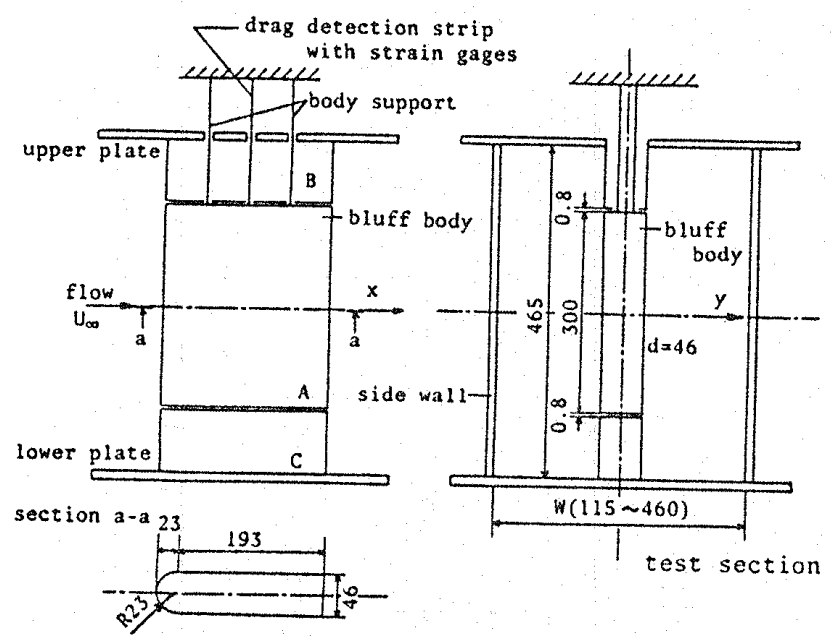

図 1 実験装政概略（抵抗湖定用供試物体）
考えられる。なお，物体の上流 $500 \mathrm{~mm}$ における断面 の流れ（主流）の速度 U一分布は一様（物体左右の速 度差: $3 \%$ 以下, 乱れ強さ: $0.5 \%$ 以下)てあった。

物体まわりの流動状態を明らかにするため，上記の 抵抗測定用物体已は別に製作した模型(断面形状は同 一であるが，份割されておらず $(H=465 \mathrm{~mm})$ ，ての 中心高さ $(H / 2)$ の位㯰の物体まわりに直径 $0.8 \mathrm{~mm}$ の压力孔 (52 個)を有する)を用い，速度分布，物体表 面上の圧力分布を測定した，速度の測定には円筒形单 孔ピト一管 (円筒直径 $2.5 \mathrm{~mm}$, 测定孔直径 $0.3 \mathrm{~mm}$ ) および熱線流速計を，玏力の湖定には傾斜管マノメ一 夕を使用した。また，物体後流中に生起する渦の卓越 周波数を熱線流速計と周波数分析器を用いて椡定し た。この際, 熱線流速計のプロープ (I 形) は，物体後 端より下流へ $2 d, y=d / 2$ の位置（図 1) に設置した。 図 2 に瀜放出周波数 $f$ 一測定例を示す。この場合 $150 \mathrm{~Hz}$ の卓越周波数が顕著に記録されているのがわ かる、なお，物体・はり系の一次固有振動数は 3.11 $\mathrm{Hz}$ (測定值)であった。

以上の諸測定を, 種々の主流速度 $U_{\infty}[=5 \sim 30 \mathrm{~m} / \mathrm{s}$ $\left.\left(R_{e}=(1.5 \sim 9.0) \times 10^{4}\right)\right],>$ ロッケージ比 $d / W[0.1 \sim 0.4$, $d=46 \mathrm{~mm}$ (一定)]に対して行い，抵抗および流動特 性に対する $d / W$ の影臨を明らかにするための実験結 果を得た。

また，物体後流領域のフローパターンを観察するた め，上記物体の $1 / 2$ 縮尺裺型（可視化実験の場合のみ 使用) 客, 幅 $310 \mathrm{~mm}$, 深さ $150 \mathrm{~mm}$, 曼さ $1000 \mathrm{~mm}$ の測定部をもつ回流水㡟中の中心位盖に設置（測定部 入口より $200 \mathrm{~mm}$ 後方) ᄂ, 測定部の中心高さの面を 光切断し，染料注入管 (外径: $1.0 \mathrm{~mm}$, 内径: 0.8 $\mathrm{mm}$ )より注入した染料(フレオレセインナトリウム水 溶液）により可視化，観察し流脈線の挙動を明らかに

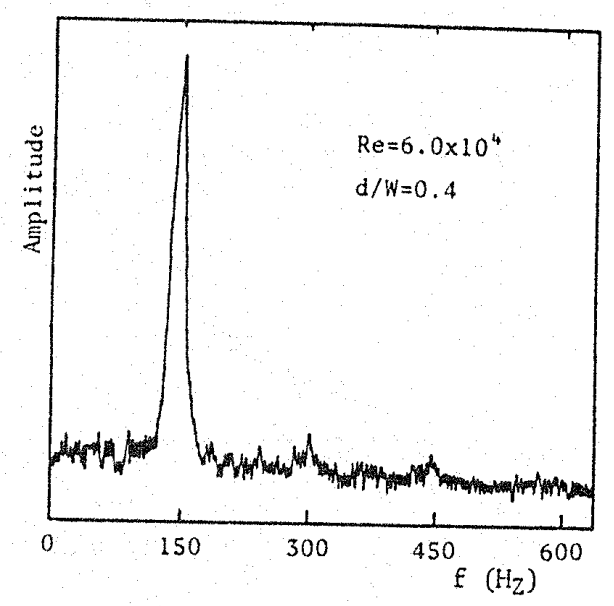

図 2 卓越周波数 
するとともに，物体後端角部より放出される渦の脤動 数をストップウォッチを使って測定した。本実験は， 別に用意した流路壁を取付けることにより $d / W=0.1$ 〜0.4の範囲で行った。この $R_{e}$ の範囲は, 風洞実験に おけるそれよりかなり小さいが，後流でのフローパタ ーンの定性的特性は，概略把挃できるものと考えられ る.

\section{3. 实駼結果と教祭}

$3 \cdot 1$ 抵抗特性 まず供試物体が受ける流体力（流 動抵抗力） $D$ に対するプロッケージ比 $d / W$ の影響に ついて実験的な検討を加えた。

本供試物体の抵抗係数 $C_{D}$ を次式で定義する。

$$
C_{D}=D /\left(\frac{1}{2} A \rho U_{\infty}^{2}\right)
$$

ここで，D測定される抵抗力， $A$ は物体の主流方向 に垂直な投影面積， $\rho$ は空気密度である。

図 3 に，抵抗係数とブロッケージ比との関係を示す (図中，○，の，印)。図 3 にみられるように, $C_{D}$ は $d / W$ とともに增加し，その增加率は $d / W$ が大きいほ ど大きくなっている。本結果は $R_{e}$ が $(4.5 \sim 7.5) \times 10^{4}$ の範囲であるが, $d / W=0.4$ の場合を除き $C_{D}$ は $R_{e}$ に あまり依存しないことがわかる．図 3 には参考のため に円柱に対する結果( ${ }^{(4)}$ も示したが，供試物体の $C_{D}$ は 円柱のそれよりかなり小さい．円柱の場合 $C_{D}$ は $d / W$ $\lesssim 0.05$ て一定值になり，ブロッケージ比の影譬をほと んど受けなくなるものと考えられる。

図 3 中の $\Delta, \Delta, \Delta$ 印の結果は抵抗係数を算出する 際，主流速度 $U_{\infty}$ の代わりに物体と測定部側壁間の速 度 $U_{\infty}^{\prime}$ (本夷験ではこれを前縁より $x / d=4.26$, 物体。

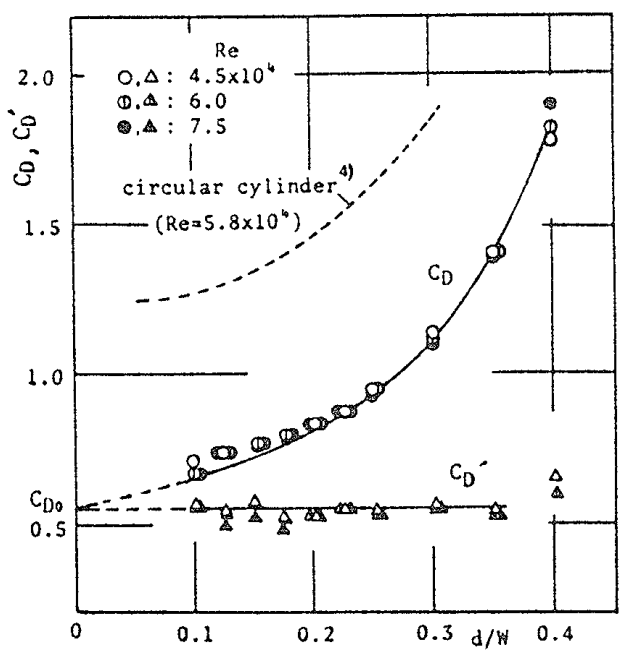

図 3 抵抗係数に及浔すフロッケージ比の影繁
側壁間の中央の位置で測定した。これは物体上に生ず る境界圆外縁の速度にほ等しい）を用いて求めたす の (これを修正抵抗係数 $C_{0}^{\prime}$ と記す)である.ブロッケ

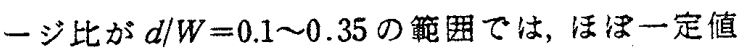

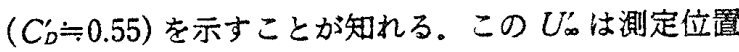

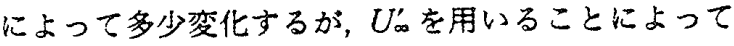
$d / W<0.35$ においては, ブロッケージ比によらず $C_{D}$ を整理できうることを示している。ささに $d / W \rightarrow 0$, すなおちブロッケージ比の影響がなくなった極限て

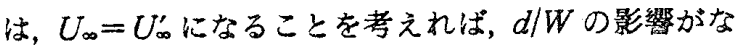
い場合の基準抵抗係数 $C_{D 0}$ は， $U_{\infty}^{\prime}$ を采入して求めた 修正抵抗係数 $C_{D}^{\prime}$ に近いものと思われる。 $d / W<0.1 の$ 詳細については今後検討を加えていくがおちらく破 線で示したような傾向をとるものと考えられる。

図 4 に, $C_{D}$ と $R_{e}$ との関係を示す。 $C_{D}$ 注概して $R_{e}$

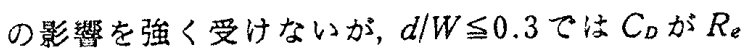
の增加とともに減少するのに対し， $d / W=0.4$ ては逆

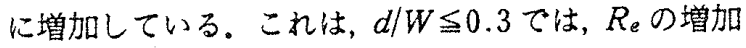
とともに物体および風洞側壁面上の境界層排除厚さが 減少して流路の有効面積が増加するため, 平均流速が 減少することになる。 その結果 $C_{D}$ が減少するものと 思われる.また， $d / W=0.4$ の場合には，その流動形態 が $d / W \leqq 0.3$ の場合とは $3 \cdot 2 \cdot 1$ 項で述べるうに本 貿的に異なることなどに起因するものと考えられる。

$3 \cdot 2$ 流動特性 上記のブロッケージ比の影響を 供試物体まわりの流動特性から检討を加えるため，压 力分布, 速度分布, 後流中の渦の卓越周波数などの測 定,およびフローパターンの可視化を試みた。

$3 \cdot 2 \cdot 1$ 圧力分布 図 5 に供試物体まうりの圧力 分有の湘定例 $\left(R_{e}=6.0 \times 10^{4}, d / W=0.1\right.$ および 0.4) を示す。図 5 中の破線拈よび実線の矢印は，それぞれ

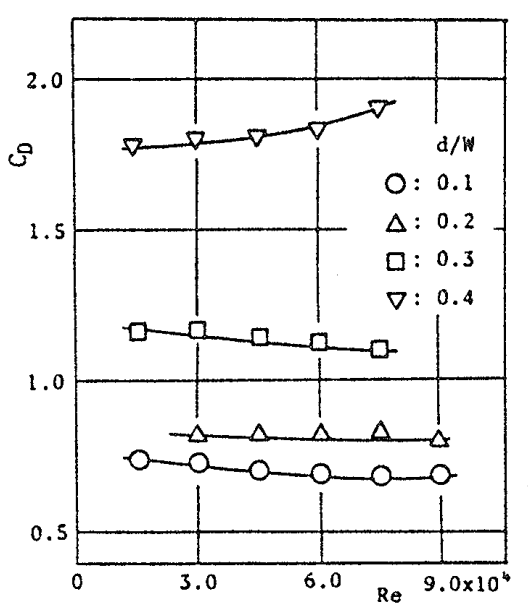

図 4 抵抗係数に及涩すレイノルズ数の影響 
正林よ゙負の圧力の大きさを王力係数 $C_{p}[=(P$ $\left.-P_{s}\right) /\left(\rho U_{\infty}^{2} / 2\right), P$ : 圧力, $P_{s}$ : 测定部内静圧]で示し たものである. 圧力分布は，中心線に対して対称であ ったので, 図 5 の上半に $d / W=0.1$ の場合の結果を, 下半に $d / W=0.4$ の場合のそれを示す。物体に沿う王 力は，物体前縁のよどみ点付近で正圧であるが，下流 にいくと負の压力となり負压が最大となる。その後負 圧量は隇少するが，半円前緑と側面接合部から約 $d / 2$ 下流の物体側端面でほぼ定の負圧量になる。これは 摩擦損失が極めて小さいことを示している.プロッケ 一ジ比が大きくなる（物体と測定部側壁の間げきが小 さくなる）と，物体近くの流れが加速されて流速が大 きくなる結果, 負の圧力值が全体に大きくなってい る。このことは，物体底部面における圧力に拈いても 同様で， $d / W$ が大きいほど，負王量は大きく，生力抵 抗が增大することがわかる， $R_{e}=(1.5 \sim 9.0) \times 10^{4}$ に変 化させた場合にちいても同様の測定を行ったが類似の

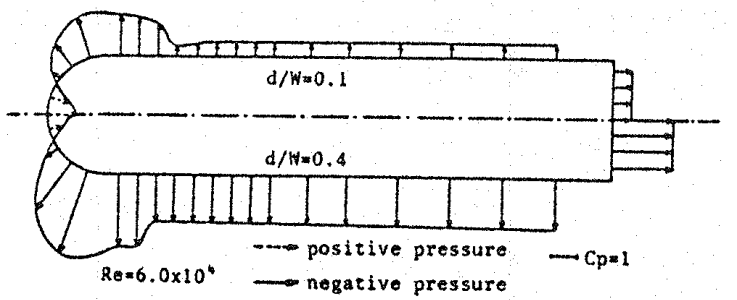

図 5 物体まわりの圧力分布

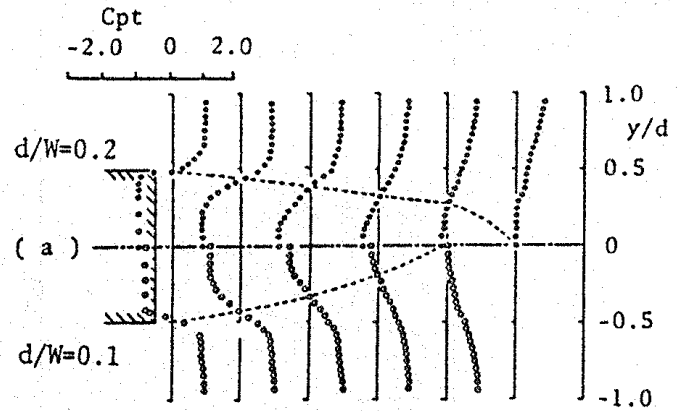

(a)
結果を䄍た。

図6に物体底部面の中心における圧力 $P_{b}$ の压力係 数 $C_{p_{b}}$ とレイノルズ数 $R_{e}$ との関係を示す.プロッケ 一ジ比が小さい場合 $(d / W=0.1,0.2), C_{p b}$ は $R_{e}$ にあま り依存しないが, $d / W$ が 0.4 と大きくなると $R_{e}$ の影 響を強く受け， $R_{e}>4 \times 10^{4}$ になると負仕は著しく增 大するようになる。これは後に示す後流中の圧力分布 および流れの可視化実験からもわかるように, $d / W=$ 0.4 の場合には，後流の流動状態が非対称になるなど

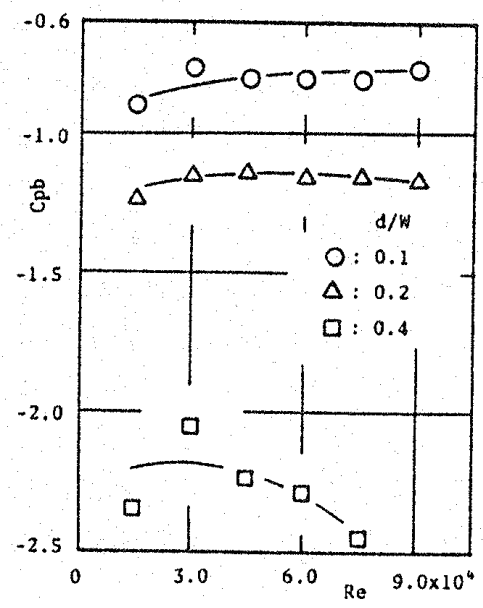

図 6 底部面生力係数とレイノルズ数との関係

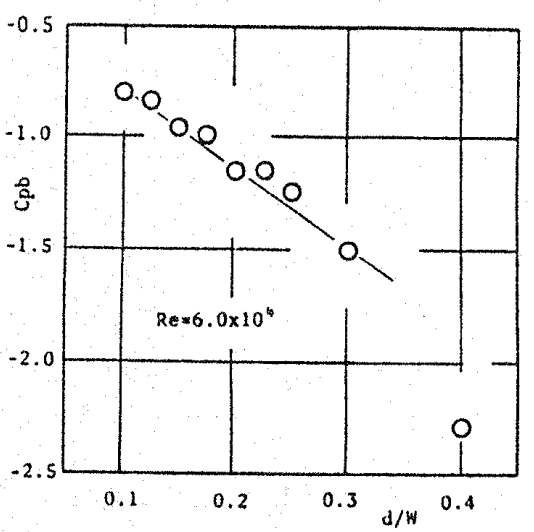

図 7 底部面珐力係数とプロックージ比との関係

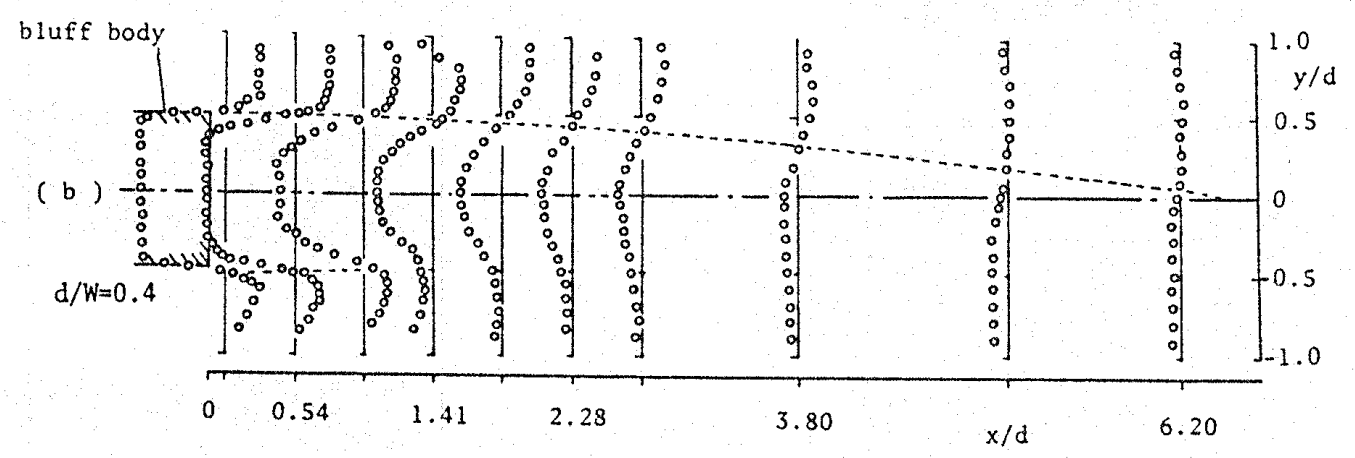

(b)

図 8 後流内の圧力分布 $\left(R_{e}=6.0 \times 10^{4}\right)$ 
フロッケージ比の影嚮を著しく強く受けることによ

る.

底部面圧力係数 $C_{\rho b}$ とブロッケージ比 $d / W$ の関係 $\left(R_{e}=6.0 \times 10^{4}\right)$ を図 7 に示す. $C_{p b}$ は $d / W$ が增加する と滅少し， $d / W$ の影響を強く受けるが,とくに $d / W$ $>0.3$ になると顕著であることがわかる。

図 8 に, 後流内の全圧力分布の変化の様子を圧力係 数 $C_{p t}$ を用いて示す。 $d / W=0.1,0.2$ の場合〔図 8 (a)]，その分布形は中心線に刘して対称であったの で，それぞれ半分の領域の結果を示す。また，図 8 中の 破線は $C_{p}=0$ の位置を結んだものであり，後流領域 とみなしうるものである。一方， $d / W=0.4$ の場合 (図 8 (b)], 全压力分布屾非対称であり, 後流領域寻著し く広がり大きく偏流していることがわかる、いずれも 後流領域 (破線で囲まれた部分) 内での全压は， $d / W か ゙$ 大きくなるとともに減少すること，またその長さ（後 流領域の下流方向への長さ） $l / d$ 洁, $d / W=0.1,0.2,0.4$ に対して，それそれれ $1.78,2.26,6.9$ てあり，d/Wの 増加とともに急激に大きくなることがわかる。

$3 \cdot 2 \cdot 2$ 速度分布図 $9 \mathrm{k}, d / W=0.1,0.2,0.4$ の各場合における物体と測定部側壁との間の速度分布

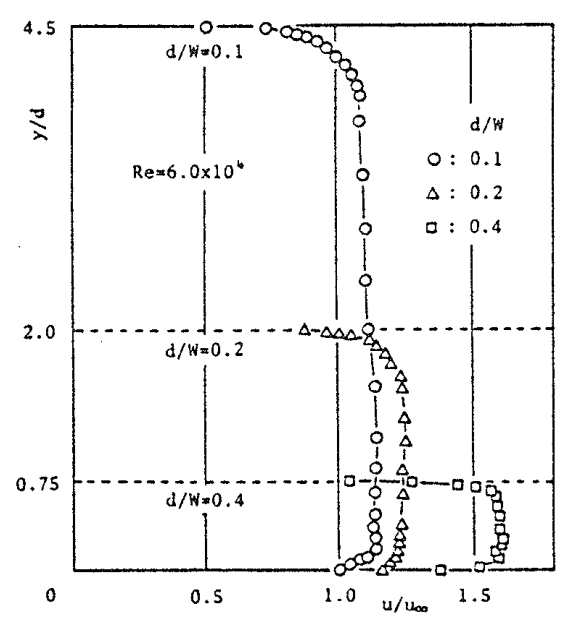

図 9 物体・側壁面の速度分布

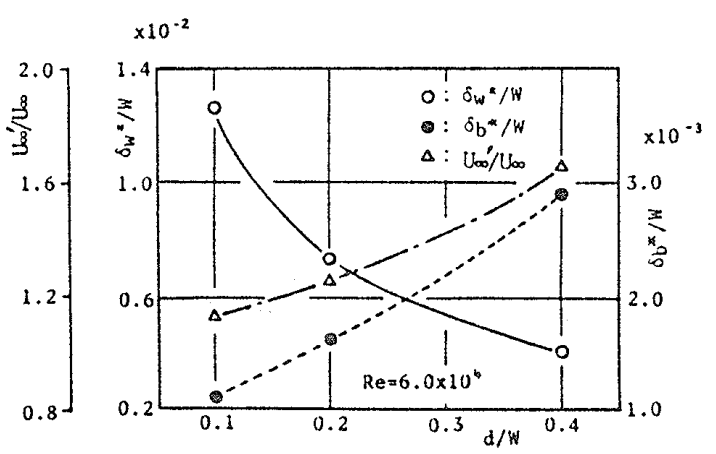

図 10 境界層排除厚さに及㳆す $d / W$ の影嫘
(物体前縁から $x / d=4.26$ の位置”, $R_{e}=6.0 \times 10^{4}$ ) を示 す. 速度の最大值は， $d / W$ の增加（物体と側壁との間 の距離の滅少)とともに大きくなること、また流れが 加速される結果側壁面上の境界層厚さか薄くなること などがわかる。境界層外側の主流領域における分布形 は，比較的平らな形となっていることもわかる。

上記速度分布の測定結果をもとに算出した境界層排 除厚さ $\delta_{w}^{*}$ (側壁面上)， $\delta_{b}^{*}$ (物体面上) と $d / W$ との関 係を図 10 に示す。境界層排除厚さ $\delta^{*}$ は,

$$
\delta^{*}=\int_{0}^{\delta}\left(1-\frac{u}{u_{b}}\right) d y
$$

で算出した。 $\delta$ は境界層厚さ，uは速度，的は境界層

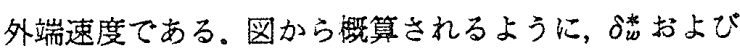
$\delta_{b}^{*}$ の值は， $d / W$ の增加とともに物体・側壁間の距離 が小さくなり流速が大きくなるため減少すること，ま

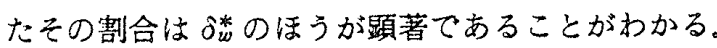

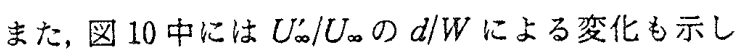
てある。 $U_{\infty}^{\prime} / U_{\infty}$ は $d / W$ の增加とともにほ淔線的に 增加することがわかる。この速度比は境界層排除暻さ を考えると次式で表される。

$$
\frac{U_{\infty}}{U_{\infty}^{\prime}}=1-\frac{d}{W}-2 \frac{\delta_{b}^{*}+\delta_{w}^{*}}{W}=K
$$

$U_{\infty}^{\prime}, \delta_{b}^{*}, \delta_{w}^{*}$ は $R_{e}$ が一定であっても距䆶 $x$ に依存する ので，x方向に積分平均化した値をとるべきであるが， 図 10 から各因子の影響度合が類推できる。すなわち $U_{\infty} / U_{\infty}^{\prime}$ に対しては $d / W$ が主因子であり，境界層の影 楳因子 $2\left(\delta_{0}^{*}+\delta_{w}^{*}\right) / W$ は相対的に小さいことが知れる が, $R$ が小さく, $d / W$ が大きいほど, 後者の因子が

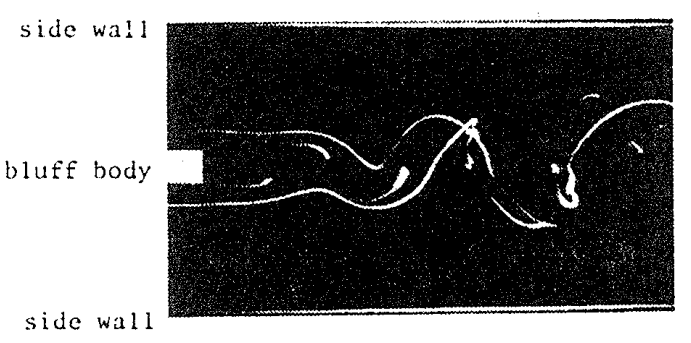

(a) $d / W=0.10$

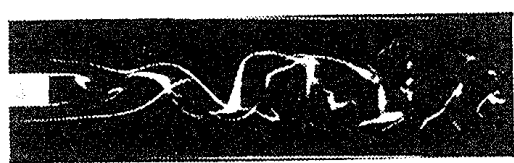

(b) $d / W=0.20$

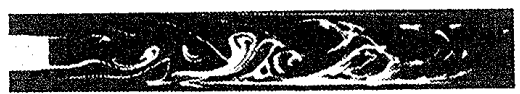

(c) $d / W=0.40$

図 11 後流領域の可視化写真 $\left(R_{e}=300\right)$ 


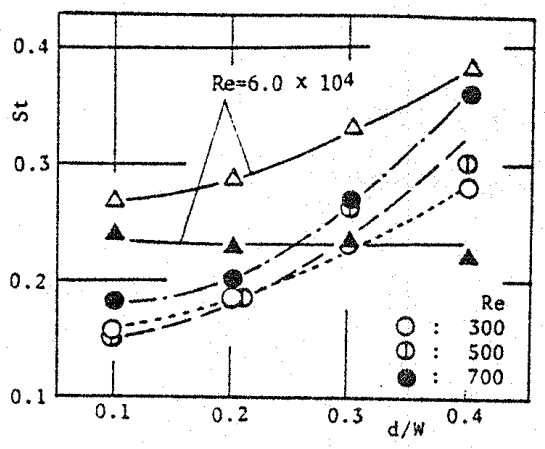

図 12 後端渦の卓越周波数とプロッケージ比との関係

効いてくるようになる。

$3 \cdot 2 \cdot 3$ 物体後流の流動様式 物体後端の角から はく離した流れがブロッケージ比によってどのように 影響されるかを明らかにするため, $R_{e}=300 〜 700 の$ 流九について可視化実験（作動流体：水，物体：前記 物体の $1 / 2$ 縮尺模型) を行った。

図11に, $R_{e}=300$ の結果 $(d / W=0.1,0.2,0.4)$ を示 す、図11(a)にみられるように，物体後流中にはカル マン渦が観察される、後流の流動状態は, プロッケー ジ比の影響を強く受け, $d / W の$ 增加とともに渦の間 隔が小さくなることがわかる。また， $d / W=0.4$ になる と, 後流は偏流し下側の壁に付着しているのが認めら れるが，カルマン渦は規則的に生起し後流の側壁への 付着が不安定になったり，切換わったりすることはな かった。このことは $R_{e}$ が大きく異なる前記の場合 $\left(R_{e}=6.0 \times 10^{4}\right.$ の場合の後流の圧力分布の測定結果) に おいても生起した。

図 12 にストローハル数 $S_{t}\left(=f d / U_{\infty}\right)$ とブロッケー ジ比との関係を示す. $S t は, d / W$ の影㗽をより強く受 け，その增大とともに增加する。図 12 に法, $R_{e}=6.0 \times$ $10^{4}$ の結果（風洞，熱線流速計，周波数分析器を使用儿 た実験）も併せ記入した。この場合（図 12 中 $\Delta$ 印）も 前記と同様の傾向を示すことが知れる、図 12 中の山印 は， $S_{t}$ を算出する際，主流速度 $U_{\infty}$ の代わりに, $C_{D}^{\prime}$ の 計算に用いた物体・測定部側壁間の速度 $U_{\infty}^{\prime}$ を使った 結果である、図12にみられるように, U⿺尢丶使って求 めた $S_{t}$ の分布は $d / W$ に依存せず，活涩一定值をとる こと，すなわち渦発生の振動数 $f$ は， $U_{\infty}^{\prime}$ に比例して ほ果值線的に変化すること $\left(f \propto U_{\infty}^{\prime}\right)$ がわかる。また， $U_{\infty}^{\prime}$ を導入した場合, $d / W \gtrsim 0.35 て ゙ C_{D}^{\prime}$ が偏流する後

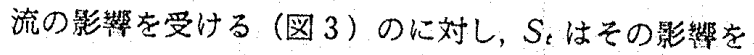
あまり受けないことがわかる。

3.3 修正抵抗係数， $3 \cdot 2$ 節までにおいて，供試鈍 頭物体の流力特性に対するブロッケージ比 $d / W$ の影
響を実験的に明らかにした。これらの結果をもとに， 串用的に重要な $d / W$ の影響を受计ない基準抵抗係数 $C_{D 0}$ を, 修正抵抗保数 $C_{D}^{\prime}(3 \cdot 1$ 節参照 $)$ を用いて求める と次式となる。すすなっ，本実験筙囲 $\left[R_{e}=(4.5 \sim 7.5)\right.$ $\left.\times 10^{4}, d / W=0.1 \sim 0.35\right)$ 内で,

$$
C_{D 0}=K^{2} \cdot C_{D}
$$

である $[K$ は式 $(3)$ 参照 $]$ 。この整理式によって, 垂直 底部面をもつ二次元鈍頭物体の抵抗係数をある程度評 価することができるものと思われる。

\section{4. 結 論}

半円形状の前縁を有し後端部に垂直底部面をもつ二 次元䤭頭物体について，その流力特性に及沽すブロッ ケージ比 $d / W$ の影響を, 抵抗力, 圧力分布, 速度分 布，物体後端角部から放出される渦の卓越周波数の湘 定，および流れの可視化観察などをもとに実験的に検 討した．結果は，以下のように要約できる。

(1) 物体入衝突する主流速度 $U_{\infty}$ を用いた抵抗係 数 $C_{0}[$ 式 (1)]は, プロッケージ比 $d / W$ の增加ととも に增加し，とくに $d / W \gtrsim 0.35$ でその影熋が著しい.

（2）物体・側壁間速度 $U_{\infty}^{\prime}$ を用いた修正抵抗保数

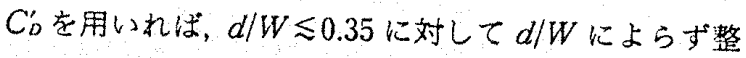
理でき，ほほ一定值をとる。

（3）プロッケージ比の影篹がない基染抵抗係数

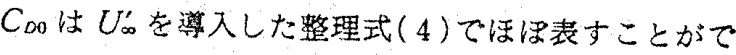
きる.

（4） $d / W \geq 0.35$ では, 底部面下流の流れが偏流し て側壁面に付着する流動形態となり，生力抵抗が著し く增大する。

（5） $d / W$ の增大とともにU心が增大し，物体およ

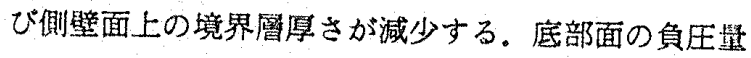
も增大寸る。

（6）物体後端角部からの渦放出周波数 $f$ は， $U_{\infty}^{\prime}$ に比例してほほ直線的に変化する。

$$
\text { 文献 }
$$

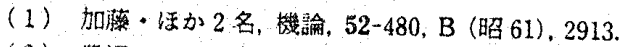

(2) 器沢・活か2 名、自動車技術, 39-11 (昭 60), 1292.

(3) Rosenhead, L. and Schwabe, M., Proc. R. Soc. London, Ser. A, 129 (1930), 115.

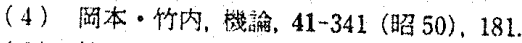

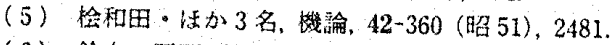

（6）跉木 - 平野, 機睮, 44-385 (昭 53)，3044.

(7) Farell, 保加 3 名. Trans. ASME, Ser. I, 99-3 (1977), 470.

（8）江滪。任汃 2 名，譏論，49-447，B (昭 58)，2363. 